\title{
ISLAMIC POPULISM POLITICS AND ITS THREAT TO INDONESIAN DEMOCRACY
}

\author{
Zainuddin Syarif and Abd Hannan \\ Institute Agama Islam Negeri Madura, Jawa Timur, Indonesia \\ email: doktorzainuddinsyarif@gmail.com, \\ hannan.taufiqi@gmail.com
}

Abstract: The study focuses on discussing the phenomena
of Islamic populism politics, its role and impact to the future Indonesian democracy. More specifically this study addressed two major issues, namely Islamic populism, and democracy in Indonesia. By using qualitative study and analysis through critical sociology theory, this study found that the phenomena of Islamic populism as a global political phenomenon which occurred in numerous countries in the world affected the process of democracy in Indonesia. This is shown by the occurrance of primordialism issue, mainly roots from the Islamic identity. In fact, the problem of Islamic populism politics for the construction of Indonesian democracy system could be seen from two factors; First, Islamic populism politics which practically uses the religion issue has triggered religious intolerance. This gives impacts on the uprise of exclusivism which ends up in sentimental behavior; Second, exploitation of Islamic populism issue gives negative consequences on the incline of intolerance behavior trend in politic sector both politics in the legislative area, especially the political dynamics and at the executive level.

الملخص: تركز الدراسة على مناقشة ظواهر السياسة الشعوبية الإسلامية ودورها وتأثيرها

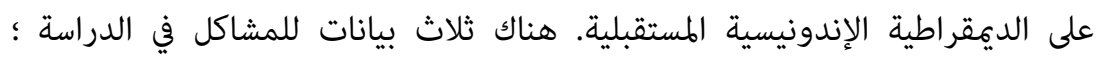

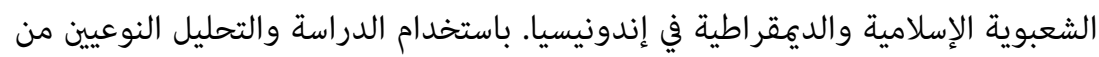

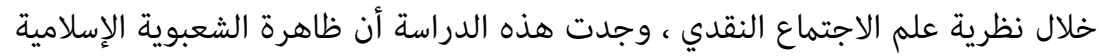

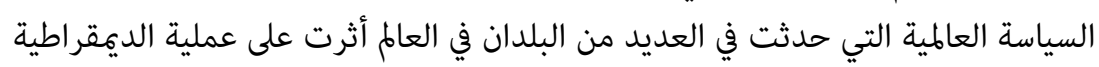

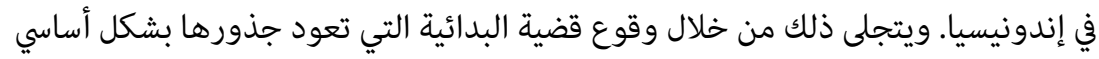
إلى الهوية الإسلامية. في الواقع ، يمكن رؤية مشكلة استخدام السياسة الشعوبية الإسلامية 
لبناء نظام ديمقراطي إندونيسي من عاملين ؛ أولاً ، تسببت السياسة الشعوبية الإسلامية

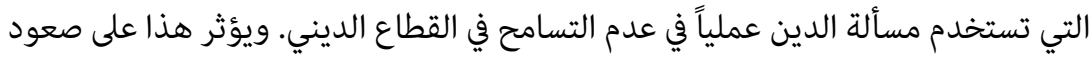

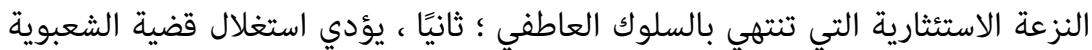

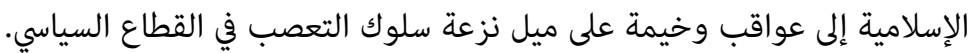

Abstrak: Studi ini fokus membahas fenomena politik populisme Islam, peran dan pengaruhnya terhadap masa depan demokrasi di Indonesia. Terdapat dua permasalahan penelitian yang diangkat dalam kajian ini; fenomena populisme Islam, dan terakhir adalah demokrasi di Indonesia. Dengan menggunakan jenis penelitian kualitatif dan analisa melalui teori sosiologi kritis, studi ini mendapati temuan bahwa fenomena populuisme Islam yang terjadi di banyak negara dunia, saat ini juga telah mewarnai demokratisasi di Indonesia. Demikian ditandai oleh mengemukanya penggunaan isu primordialisme, terutama yang mengakar pada aspek identitas. Dalam kenyataannya, problem penggunaan politik populisme Islam terhadap bangunan sistem demokrasi di Indonesia dapat dilihat dari dua hal; Pertama, politik populisme Islam yang dalam praktiknya memanfaatkan isu agama telah menimbulkan intoleransi di sektor keagamaan. Hal ini berdampak negatif terhadap bangkitnya eksklusivisme yang berujung pada perilaku anarkisme dan kekerasan yang mengatasnmakan agama; Kedua, eksploitasi isu populisme Islam berakibat buruk terhadap realitas politik. Baik politik di wilayah legislatif, terlebih lagi dinamika politik di level eksekutif.

Keywords: Islamic Populism, democracy, post-truth, religion issues, intolerance, politics.

\section{INTRODUCTION}

In the last two decades, particularly post-reform 1998, dialogues over the connection of Islam and democracy has gained enormous attention from many parties. ${ }^{1}$ The dialogues were built both theoretically and

1 Abd A'la, Jahiliyah Kontemporer Dan Hegemoni Nalar Kekerasan (Yogyakarta: LKiS, 2014), 2-7; Masdar Hilmy, Islamisme and Democrazy in Indonesia (Sinagapore: Institute of Southest Asian Studies, 2010). 
practically related to the power contestation across the elector, the region, and the nation. In a theoretical scope, discourses of Islam and democracy connection occurred in questioning: is Islam as the major religion in Indonesia suitable with democracy system? Considering Islam has been facing issues of classical stigma such as radicalism, fundamentalism, and exclusivism until today. ${ }^{2}$ Several acts of terror and anarchism in the name of Islam which were claimed to be taken by right extreme groups more or less have raised doubts from many parties if Islam will truly be in-line with democracy system.

Meanwhile, in a practical scope, dialogues of Islam and democracy connection have found a room along with various contemporary politics dynamics, that is the uprise of political movements under the platform of Islamic populism which in the last several years have been actively participating in taking parts on the power constelation stage in Indonesia, both in regional and national level. In the regional politics level, the revival occurrence of political movements with Islamic populism appeared in the local government election (PILKADA) of Jakarta in 2017, particularly after the huge mass mobilization across various Islamic groups, namely Islamic Defense Action (Aksi Bela Islam) 212 and 411. The use of primordialism issue in the name of religion as well as all forms of symbolization does not only trigger political chaos in a broad scale, but also threaten democracy system. Meanwhile, in the national politics level, the revival occurrence of political movements with Islamic populism remarked in the presidential election (PILPRES) in 2019. Not apart from politics stage of local government election (PILKADA) Jakarta in 2017, the politics stage of presidential election (PILPRES) in 2019 beheld discourses of primordialism instead of contesting ideas and thoughts. The revival of identity politics in the name of religion which politically influenced the local government election (PILKADA) of DKI Jakarta in fact impacted national politics stage of presidential election (PILPRES) in 2019.

2 Nicholas Provencher, 'Is Islam Compatible with Democracy: A Critical Reexamination of Existing Theory to Establish Renewed Potential' (Prosiding, University of Arkansas at Monticello, Georgia, 2011); Steven Ryan Hofmann, 'Islam and Democracy: Micro-Level Indications of Compatibility', Comparative Political Studies 37, no. 6 (1 August 2004): 652-76, https://doi.org/10.1177/0010414004265881. 
Historically, the rise of Islamic populism politics movements in democracy rooms in Indonesia is indeed not a new thing. Such phenomenon has been long happening, even before Indonesia achieved its stat us as an independent country. ${ }^{3}$ At recent time, Islamic populism politics is aimed at fighting against and confronting colonialist groups which at those time had an interest to run imperialism and pillage of Indonesian archipelago. In short, the connection of religion and Islamic populism politics is seen as two sides of a penny. When there is power contestancy, practically there is religion politics narration in the name of Islam. Sociologically, the massive use of religion (Islam) issue as a politics commodity in Indonesia is strongly associated with demographic characteristics of Indonesia which so far has been known as a country with muslim population majority. ${ }^{4}$

However, the uprise of Islamic populism politics in recent years shows novel and intriguing realities, mainly after Islamic Defense Action (Aksi Bela Islam) was held. In this circumstance, it is clearly shown how Islamic populism politics has been more systematically mobilized and organized nowadays than in previous era. Political narratives do not only contain power issue, but also widespread onto populic rooms of clashes between religious and ethnic groups. In such relation, populism emerges in public discussions through the playing victim narrative as if the muslim majority is oppressed by the system or certain politics power which was considered to be in opposition in their rights and interests. At the same time, they see themselves as marginalized social groups due to the hegemony of capitalistic economy of the Chinese minor group, which they call the migrants (the colonialists). ${ }^{5}$

Observing today's politics dynamics, and researching the model of Islamic populism politics narration during the local government election (PILKADA) in Jakarta and presidential election (PILPRES) in 2019, logically many parties claimed that democracy politics atmosphere in Indonesia has now been in tidal situation as a consequence of global politics impact which was popular with the

3 Abd Qohar, 'Politik dan Islam di Indonesia', Jurnal TAPIs 14, no. 2 (2017): 8.

4 Supriyanto Abdi, 'Muslim Politics and Democracy In Indonesia', Jurnal Millah 6, no. 1 (Agustus 2007): 17.

5 Endi Aulia Garadian, 'Membaca Populisme Islam Model Baru', Studia Islamika 24, no. 2 (2017): 379-93 
phenomena of post-truth politics. ${ }^{6}$ The multitude of elite groups' politics maneuver that exploit identity issues, used intimidation, as well as hate speech, and propaganda has indicated the presence of post-truth politics. ${ }^{7}$ Political intimidation by narrations of dismissing Indonesia 2030, the huge religious mobilization, Islamic Defense Action (Aksi Bela Islam) 212-411, the role of identity politics played in the terms of native and foreign, the discourse of communism revival characterized by the social political economical imperialism of Chinese groups towards muslim native society. All those political narrations are parts of post-truth politics intricacy. ${ }^{8}$ Their impacts do not only hinder leadership succession, but also threaten in democracy in Indonesia.

\section{GENEALOGY OF POST-TRUTH: HISTORICAL AND CONCEPTUAL READINGS}

Genealogically, discussions about post-truth politics directly lead to post-modernism dialogues, since there is similar epistimological base in post-truth and post-modernism. ${ }^{9}$ To describe, the correlation between these two terms is analogous with both sides of a penny. However, it is not negating one another, but it is supporting and relates very closely. If post-modernism is the main, then post-truth is the embodiment of current culture produced by post-modernism. ${ }^{10}$

6 Amilin, 'Pengaruh Hoaks Politik Dalam Era Post-Truth Terhadap Ketahanan Nasional Dan Dampaknya Pada Kelangsungan Pembangunan Nasional', Jurnal Kajian Lemhannas RI 36, no. (September 2019), http://www.lemhannas.go.id/images/ Publikasi_Humas/Jurnal/Jurnal_Edisi_39_September_2019.pdf.

7 A $\bar{b} d$ Hannan, 'Firehouse of Falsehood; Politik Pascakebeneran Dan Ancamannya Terhadap Bangunan Demokrasi Indonesia', in Digital Islam, Education and Youth; Changing Landscape of Indonesian Islam, vol. 19 (the 19 Annual International Conference on Islamic Studies (AICIS 19), Belgium: Euoropean Alliance fo Innovation (EAI), 2019).

8 Rangga Kusumo and Hurriyah Hurriyah, 'Populisme Islam di Indonesia: Studi Kasus Aksi Bela Islam oleh GNPF-MUI Tahun 2016-2017', Jurnal Politik 4, no. 1 (15 February 2019): 87-100.

9 Colin Wight, 'Post-Truth, Postmodernism and Alternative Facts', New Perspectives 26, no. 3 (1 October 2018): 17-29, https://doi. org/10.1177/2336825X1802600302.

${ }^{10}$ Frank Fischer, 'Knowledge Politics and Post-Truth in Climate Denial: On the Social Construction of Alternative Facts', Critical Policy Studies 13, no. 2 (3 April 2019): 133-52, https://doi.org/10.1080/19460171.2019.1602067. 
According to Stephen Colbert, in several circumstances post-truth indeed has similarity with the term truthiness which means a belief on something even though it is not supported by the available facts. As a belief, post-truth works out of logical laws. Instead, it tends to oppose the common sense, either unholding the data, or institutional legitimation just as a general thesis formation. The main target of post-truth is the emotional side of an individual. Consequently, the narration built is more on primordial issue which in direct contact with personal areas and believes. The negative effect occurred is the dichotomy of common sense and belief. The logic and feeling are asynchronous in dialectic-productive relation, both negate one another and lead to destructive relation. The climax point of all is the presence of sentimental attitude and behavior. An individual takes an action not because of the encouragement of good logic, yet because of emotion, even sometimes it leads to fanatism. ${ }^{11}$ Fanatism will then be a clarifier variable of why people who experience a politics sign of post-truth in several occasions tend to show militancy in attitude and behavior.

\section{POLITICS OF POST-TRUTH AND PROPAGANDA OF FIREHOUSE OF FALSEHOOD (FOF)}

Paul and Matthews in Golose as quoted by Petrus (2019) mentioned three (3) main characteristics of $F o F$, they are; 1) lacks commitment to consistency; 2) lacks commitment to objective reality; 3) High volume, multichannels, rapid, repetitive and continuous. ${ }^{12}$ Lacks commitment to consistency has a meaning that FoF underlies the work on widely spreading information or news which is not only accurate, but also reverse. FoF puts facts aside, showing subjective narrations that contain negative issues and bias on fact reverse. To strengthen its position, FoF holds certain organizations which previously have had political cooperation with. Organizations such as politics consultant, information media, survey service, and other politics services, are driven to influence the public opinion. In this limitation, electoral

${ }^{11}$ Washington Times, 'Stephen Colbert's “truthiness" Word Describes Campaign Rhetoric', Washington Times, 18 August 2016, https://www.washingtontimes.com/ news/2016/aug/18/stephen-colberts-truthiness-word-describes-campaig/.

${ }^{12}$ Christopher Paul and Miriam Matthews, The Russian 'Firehose of Falsehood' Propaganda Model: Why It Might Work and Options to Counter It (RAND Corporation, 2016), https://doi.org/10.7249/PE198. 
behavior of the voters are more greatly affected by data than facts, more to image-building than reality-building, more to symbols than values.The frequency of spreading lies which is conducted massively will finally involute lies as agreed truth. This FoF strategy was used by Trump when Cambridge Analytica was presented to ease his pragmatic political interest.

The other political features of FoF is Lacks Commitment to Consistency, which means inconsistency in presenting news and information given. FoF works in making news overlapping and sloppy towards one another, each information media intersects with the others, and hence this causes public instability and chaos, instead of stability, as a result of information uncertainty. ${ }^{13}$ In this connection, $F o F$ plays strategic roles and functions in creating doubts, confusion and tense, therefore the meaning of truth becomes bias and fading. $F o F$ invokes hypereality world above the true reality, thereby consciousness system of an individual generates hallucinations and uncertainty. Psychologically, information uncertainty tends to make an individual easily influenced, by increasing the volume of publication frequency and widespread. Therefore, $F o F$ information system works in repetitive rythms. The work system of $F o F$ is not under the framework of the objectivity, yet in the number of rythms and their repetitive frequency.

The last characteristics of $F o F$ as a political instrument of posttruth are high volume, multichannels, rapid, repetitive and continuous, which are the model of untruth information spreading and enormous fear. Deception and terror are widely dispersed in the public, both in on-line and off-line sectors. Every public area where people gather, or social media where netizens browse the internet turns out to be a dominant room where wrong information and fake news is well widespread. ${ }^{14}$ Consequently, social spaces are filled with fake news, causing truth and objectivity to hardly achieve. Public dependence on social media information, coupled with the lack of critical evaluation on information as a result of the weakening of literacy culture, both book and media literacy, in certain situation keeps $F o F$ presence

${ }^{13}$ Rendy Prasetya, 'Criticizing Russian Propaganda Firehose of the Falsehood from the Framework of Social Network Analysis', 21 November 2019.

${ }^{14}$ Lilla Vicsek, 'Halim Rane, Jacqui Ewart, John Martinkus: Media Framing of the Muslim World. Conflicts, Crises and Contexts.', KOME 4, no. 1 (2016), 17. 
on being accepted, even sometimes becoming a source of reference, including in politics.

In recent development, post-truth as a phenomenon of social current trend is frequently related to global politics phenomena, particularly from political groups affiliating to right ideology. ${ }^{15}$ There are multiple global political events characterizing the trend of posttruth use as politics strategy. The success of Jair Bolsonaro in Brazil, Dutarte in Philippines, and Brexit happened in Britain (2016), Milos Zeman in Czechoslovakia (2018), Victor urban in Hungary (2010). The most phenomenal among all is the winning of Trump over Hillary Clinton in presidential election of USA (2016). ${ }^{16}$ Numerous parties thought that the uprising of Trump's political carrier which at that time used politics strategy of post-truh, significantly grabbed attentions of many world political elites, duplicating it as a strategy to gain power in each country. The revival of post-truth as a trend of global politics intricacy is in-line with the Oxford dictionary release, which in 2017 made post-truth as "Word of the Year". It was trigerred by the incline of corpus number of post truth use reaching up to 2000 percents from the previous years, 2015. The increase was mostly affected by the political momentum of The United States of America, when post-truth was identified in the phenomenon of Trump's political effect. ${ }^{17}$

${ }^{15}$ Ewen Speed and Russell Mannion, 'The Rise of Post-Truth Populism in Pluralist Liberal Democracies: Challenges for Health Policy', International Journal of Health Policy and Management 6, no. 5 (12 February 2017): 21, https://doi. org/10.15171/ijhpm.2017.19.

16 Jonathan Rose, 'Brexit, Trump, and Post-Truth Politics', Public Integrity 19, no. 6 (14 November 2017): 555-58, https://doi.org/10.1080/10999922.2017.1285540.

${ }^{17}$ Robin Lakoff, 'The Hollow Man: Donald Trump, Populism, and Post-Truth Politics', Journal of Language and Politics 16 (12 June 2017), https://doi.org/10.1075/ jlp.17022.lak.and what might it portend? This paper explores these and other questions: how have Trump's victory and his communicative strategies compromised the culture's notions of "truth" - via a continuum from "lie" through "post-truth," "truthiness," and "alternative facts" to "truth"? Is Trump - judging from his language and other communications - really a populist? And how are we to understand his many idiosyncrasies of discourse, as well as his supporters' unwillingness to worry about them?","container-title":"Journal of Language and Politics","DOI":"10.1075/ jlp.17022.lak","journalAbbreviation":"Journal of Language and Politics","title":"The hollow man: Donald Trump, populism, and post-truth politics","volume":"16","aut hor":["family":"Lakoff","given":"Robin"],"issued":"“date-parts":[[“2017”,6,12]]],"s chema":"https://github.com/citation-style-language/schema/raw/master/csl-citation. json". 
After taking Trump to the presidency, post-truth involuted as a global politics project that grabbed attentions of many world political elites. Not only in developed countries in Europe and Latin America, such as The United States of America, England, Czechoslovakia, and Brazil, but also dispersed to developing countries in Asia. In Asia, post-truth succeeded taking Rodrigo Duterte as the leader of Philippines (2016). ${ }^{18}$ The winning of Duterte inspired other Asia countries, including Indonesia which was having the ups and downs of political situation before presidential election in 2019. In Indonesia, political signs of post-truth were characterized by the occurrence of three (3) phenomena, they are politics of propaganda, dromology, and the most intriguing was politics of populism.

Theoretically, propaganda has an explanatory meaning of truth and falsehood which is developed in order to assure people to follow certain sectarian system, attitude, or behavior. ${ }^{19}$ Propaganda acquires the art of influence in such a way that other people embrace and follow every talk, even though it does not fully go with their thoughts. In political context, propaganda generally comes in the form of sensitive issues relating directly with life such as issues of economy, education, religion, and identity. The latter two, religion and identity, are the most sensitive issues which lightly give public attention. The strength of religion and identity as instrument of propaganda is situated in their characteristics which are not only in direct relation with social aspects of the people, but also in belief relation, therefore it will directly give emotional impacts such as being triggered and influenced. ${ }^{20}$ In the context of Indonesia's democracy, a phenomenon of political propaganda is illustrated in the political behavior and maneuver of political elites who in recent years tended to create their politics narrations in primordialism. Instead of showing contesting ideas and programs and offering a logical and political model, political narrations they revealed contained more provocations, targeting the emotional voters. In its practice, clear description of this propaganda politics could be found in the politics

${ }^{18}$ Nicole Curato, 'Politics of Anxiety, Politics of Hope: Penal Populism and Duterte's Rise to Power', Journal of Current Southeast Asian Affairs 35, no. 3 (December 2016): 91-109, https://doi.org/10.1177/186810341603500305.

${ }^{19}$ Hasan Alwi, Kamus Besar Bahasa Indonesia (Jakarta: Balai Pustaka, 2007).

${ }^{20}$ Haryatmoko, Dominasi Penuh Muslihat. (Jakarta: Gramedia, 2010). 
style of Prabowo during presidential election (PILPRES) in 2019. ${ }^{21}$ The release of meta-narration of dismissing Indonesia 2030, Jakarta would be sinking, the economic imperialism of foreign colonialists toward the natives/native groups, were all parts of propaganda politics figuring the political reality of Indonesian democracy in the last few years.

Besides propaganda politics, another sign of post-truth politics presence in Indonesia's democracy is the phenomenon of dromology politics. In social dicourses, the term of dromology was first introduced by Paul Virilio (1932-2018, in his book, Virilio explaining that dromology is a process of cultural acceleration supported significantly by the existence of computerized technology. ${ }^{22}$ Globalization and modernization occur in every line allowing human being to be in accellerated competitions, first come first served. In the progress, dromology changes to be an identity of post-modern society, including political world. ${ }^{23}$ In the world of politics, dromology is represented by the presence of media and information. Media with all its advancement and superiority play strategic roles and functions,

${ }^{21}$ Abd Hannan, 'Kembalinya Politik Identitas', DetikNews, 3 January 2018, https://news.detik.com/kolom/d-3796760/kembalinya-politik-identitas.

${ }^{22}$ Bahareh Bagherzadeh Samani, Hossein Pirnajmuddin, and Behnoush Akhavan, 'Paul Virilio's Dromology and the Postmodern City in Don DeLillo's Cosmopolis', ed. Maria DiBattista, Cogent Arts \& Humanities 5, no. 1 (1 January 2018): 1424600, https://doi.org/10.1080/23311983.2018.1424600.

${ }^{23}$ Rob Bartram, 'Visuality, Dromology and Time Compression: Paul Virilio's New Ocularcentrism', Time \& Society 13, no. 2-3 (27 August 2004): 285-300, https://doi.org/10.1177/0961463X04044577.by establishing conceptual links between visuality, dromology and time compression. More specifically, it establishes the mutually constitutive relationship forged between visuality and the Western cultural imperative to compress the transmission time delay of visualizing technologies. I argue that the Western cultural pursuit of ubiquitous and simultaneous vision not only creates a new form of ocularcentrism, but generates potentially detrimental consequences for ?human relations? and diminishes human control over democratic processes. The article is enriched and focused by drawing upon the recent work of Paul Virilio. Virilio?s phenomenologically inspired critique of visualizing technology prompts us to rethink visuality as an active, embodied practice constituting important lived experiences.,",container-title":’Time \& Society","DOI":"10.1177/096146 3X04044577","ISSN":"0961-463X","issue":"2-3","journalAbbreviation":"Time \& Society","note":"publisher: SAGE Publications Ltd","page":"285300","title":"Visuality, Dromology and Time Compression: Paul Virilio's New Oc ularcentrism","volume":"13","author":["family":"Bartram","given":"Rob".],"issued" :"date-parts":[[“2004",8,27]]],"schema":"https://github.com/citation-style-language/ schema/raw/master/csl-citation.json". 
mainly in carrying public opinions and affecting the voters' acts and behaviors. The strategic roles and functions of dromology politics through technology and information media, could be traced in Donald Trump's succession in the politics of The United States of America. ${ }^{24}$ By using the big data in a social media, Facebook, of which he 'stole' from a politics consultant firm, Cambridge Analytica, Trump surprisingly defeated a senior and famous politician, Hillary Clinton. In Indonesia context, dromology politics was represented by the flare of numerous agencies and the presence of buzzer. These two groups were told to be the symbol of dromology political presence, which in various political events in Indonesia played significant roles and gave impacts in changing the map of the Indonesian politics, both in the national level and local level.

Besides two indicators explained above, post-truth politics involves populism politics. Terminologically, populism has a meaning of ism which believes and upholds right, wisdom, and virtue of low level society. ${ }^{25}$ With this underlying terminology, populism politics means politics that requires defense and advocacy of low level society as well as the their interests such as welfare, economy, education, health, and so on. In several occasions, populism often becomes the most frequently used issue in public, as it is influenced by the character which is highly primary in people's lives. ${ }^{26}$ Not rarely, the term populism is identified in the existence of particular groups or classes, especially those who are socially, politically, and economically narrated as the marginals. One of populism forms which is mostly used and has a big impact is religion populism. In American political interests, populism was played by Trump on the politics of anti-muslim imigrants, as if muslim imigrants were the actors of all kinds of terror happened in America. ${ }^{27}$ Meanwhile in Indonesia, populism politics with religion (Islam) basis occurred in the narration forms of communism revival, colonialization of

${ }^{24}$ Matthew Rosenberg, Nicholas Confessore, and Carole Cadwalladr, 'How Trump Consultants Exploited the Facebook Data of Millions', The New York Times, 17 March 2018, sec. U.S., https://www.nytimes.com/2018/03/17/us/politics/cambridgeanalytica-trump-campaign.html.

${ }^{25}$ Alwi, Kamus Besar Bahasa Indonesia.

${ }^{26}$ Kusumo and Hurriyah, 'Populisme Islam di Indonesia', 88-107.

${ }^{27}$ Siti Nur Rohmah, 'Critical Discourse Analysis of Donald J Trump's Speeches' (Surabaya, UIN Sunan Ampel Surabaya, 2018). 
imigrants (Chinese) toward inlander muslims, ${ }^{28}$ issues of political and economical marginalization to the majority, in this case referring entirely to the population of Indonesian muslims.

\section{ISLAMIC POPULISM AS A PART OF POST-TRUTH POLITICS IN INDONESIA DEMOCRACY}

Terminologically, the definition of populism has various versions. However, subtantially populism contains literary meaning identical with the use of popular issues, particularly social issues directing to social groups in numerous backgrounds, such as economy, politics, culture, and similar others. ${ }^{29}$ The social groups referred to are individuals or groups who in their social relations are marginalized as a result of the politics system disoriented from their interests. Normally, populism term is identified as a part of political events generated from the other (liyan) movement groups, in this case it is the particular social groups or classes who narrate themselves as the marginalization victims of oligarchy or political power and capitalists.

Referring to the explanation of Vedi R. Hadiz (2018), social movements of the populists generally work through political channels and social organizations, particularly political groups or organizations (parties) from the right wing. ${ }^{30}$ In Egypt for an example, the populists arose from an Islamic populism politics movement, Ikhwanul Muslim, a right wing Islamic populism politics movement which at that time was a homebase of marginal groups toward an authoritarian politics system policy of Hosni Mubarak who was considered to disaccommodate their interests. The success of populist activism which was driven by the right wing Islamic groups, Ikhwanul Muslim, in Egypt, in its turn induced plenty of populist movements in other countries. ${ }^{31}$ Unexceptionally in Indonesia, mainly in early decade of

${ }^{28}$ Vedi R Hadiz and Richard Robison, 'Competing Populisms in PostAuthoritarian Indonesia', International Political Science Review 38, no. 4 (1 September 2017): 488-502, https://doi.org/10.1177/0192512117697475.

${ }^{29}$ Garadian, 'Membaca Populisme Islam Model Baru'.

${ }^{30}$ Vedi Hadiz, 'Imagine All the People? Mobilising Islamic Populism for RightWing Politics in Indonesia', Journal of Contemporary Asia 48 (6 February 2018): 1-18, https://doi.org/10.1080/00472336.2018.1433225.

${ }^{31}$ Hatib Abdul Kadir, 'Islamic Populism in Indonesia and the Middle East, Written by Vedi R. Hadiz’, Bijdragen Tot de Taal-, Land- En Volkenkunde / Journal 
2000s when transition from new order regime to democrary was on process.

Historically, the phenomena of populism in Indonesia truly went through a long walk of history, even it had existed since Indonesia was ruled under Soekarno regime. During the era of Soekarno, populism was played by elite groups to settle down the geo politics in ground level, one of them was by throwing the ideas of Nationalism, Religion, and Communism (Nasionalisme, Agama, dan Komunisme - NASAKOM) integration. Meanwhile in Soeharto era, populism was acted by class groups of students who gathered for a huge demonstration to urge Soeharto to step down his throne as a president. ${ }^{32}$ Post-reformation 98, exactly when Indonesia was going through a politics transition of the government from semi-presidential system to multi-parties presidential system, the phenomena of populism started to displace. In that situation, populism was operated more on narration and religious symbolization. The scrolling of totality democracy system characterized by the more dynamic and freedom of national politics stage, in turn gave populism politics movement in the name of religion more freedom to move up. It encompassed populism political movement on Islamic basis, including the populism politics movement on Islamic basis which was played by the right wing Islamic movement group such as an Islamic organization, Hisbut Tahrir Indonesia (HTI), and alike. ${ }^{33}$

of the Humanities and Social Sciences of Southeast Asia 173, no. 4 (1 January 2017): 594-97, https://doi.org/10.1163/22134379-17304011.

${ }^{32}$ Vedi R. Hadiz, Title-Page. In Islamic Populism in Indonesia and the Middle East (Cambridge: Cambridge University Press, 2016).

${ }^{33}$ Vedi R. Hadiz, 'A New Islamic Populism and the Contradictions of Development', Journal of Contemporary Asia 44, no. 1 (2 January 2014): 125-43, https://doi.org/10.1080/00472336.2013.832790; Syamsul Arifin et al., 'Minority Muslims and Freedom of Religion: Learning from Australian Muslims' Experiences', Indonesian Journal of Islam and Muslim Societies 9, no. 2 (25 December 2019): 295326, https://doi.org/10.18326/ijims.v9i2.295-326; Wasisto Raharjo Jati, 'Radicalism in the Perspective of Islamic-Populism: Trajectory of Political Islam in Indonesia', JIS; Journal of Indonesian Islam 7, no. 2 (1 December 2013): 268, https://doi.org/10.15642/ JIIS.2013.7.2.268-287.qualitatively, some issues considered in understanding the development are practices of secularism, multiculturalism and protection of human rights. This academic framework in comprehending the development might be claimed as a new trajectory of sociological exploration. Accordingly, this study is proposed to become a preliminary research on Muslims' freedom of religion living in secular country. This article finds that Australia is a state that consistently has 
In the beginning of its occurrence, Islamic populism groups in Indonesia was categorized as silent groups which underlied their agenda on tarbiyah or education movement. In the next interval years, these groups began to affirm their movement orientation by their involvement in practical-politics activism, carrying the vision of transnational interest. Not only to gain power in a single territory of certain countries, but more than that, to strive for the re-implementation of Islamic government system as a world's single system of governance (Khilafah Islamiyah). ${ }^{34}$ In their political activism, Islamic populists in Indonesia often exposes to confront the regime and the politics power of authoritarian groups which threaten their existence. In the political context of Indonesian democracy at recent time, the fight against Islamic populism politics later is not only aimed at the ruling elites, but also at certain ethnicity which is considered as disturbing their agenda and interest, as it was seemingly pointed at Chinese ethnicity described in a political phenomenon of Ahok. $^{35}$

Analyzing the politics progress in the last several years, both in regional and national level of politics events such as during the local government election (PILKADA) in Jakarta and presidential election (PILPRES) in 2019, democracy politics stage in Indonesia was dominated by Islamic populism politics eventuality. In the local government election (PILKADA) of Jakarta, the use of Islamic populism politics could be delineated from the massive use of religion and identity issues. A political phenomenon of Ahok in the case of Al-Maidah turned out to be a clear reference to observe the

protected its citizens' freedom of religion and the Australian government, in dealing with social and religious issues, and law enforcement, has worked professionally. However, Muslims have faced challenging realities of cases of discrimination coming from fundamentalist Christians. The cases, indeed, can be mitigated through interreligious dialogue and cooperation. This article argues that, so far, the development of Ummah in the country has been running well. Under the protection of a secular state, minority Muslims in Australian multicultural societies can enjoy their freedom of religion. Practices of inter-religious tolerance are stronger than the tensions and conflicts have happened.","container-title":"Indonesian Journal of Islam and Muslim Societies","DOI":"10.18326/ijims.v9i2.295-326","ISSN":"2406-825X, 2089-1490","issue":"2","journalAbbreviation":"Indonesian J. Islam Muslim Soc.,,"1 anguage":"en","page":"295-326","source":"DOI.org (Crossref

${ }^{34}$ Masdar Hilmy, Teologi Perlawanan,: Islamisme Dan Diskursus Demokrasi Di Indonesia Pasca Orde Baru (Yogyakarta: Kanisius, 2009), 185.

${ }^{35}$ Kusumo and Hurriyah, 'Populisme Islam di Indonesia'. 
occurrence of Islamic populism politics in Indonesian democracy. ${ }^{36}$ The case heated up along with the occurrence of religion defamation issue. The climax of all was the starting point of Islamic Defense Action (Aksi Bela Islam) 212 and 411 movements which brought up the government the urgency to take religion defamation case to court by law, and the politics deligitimation which then ended in the defeat. In this case, it was explicitly shown that the narration of populism Islam significantly does not only revive the spirit and the emotion of Indonesian muslim society, but also effectively unifies muslim society across social classes. From the labors and farmers, to the bourgeois and bureucrats. Surprisingly, all elements of various sosial classes took the moves synchronously with the same purposes and interests as an ummah unity who felt themselves as marginalized by the leader group's power of authoritarianism. ${ }^{37}$

Meanwhile, in the national politics level, the political narration of populistic Islam could be traced in the phenomenon of presidential election (PILPRES) in 2019. Quite similar to the local government election (PILKADA) of Jakarta, the model of Islamic populism narration in this level obviously stood from the use of primordialism of religion and ethnicity. Both the candidate pairs exploited classical primordialism such as the uprise of communism, communist blood and offspring, communism followers, and several others. ${ }^{38}$ The dark history of communism in Indonesian milestone was then used by Islamic populism groups to raise their politics offer. Several other issues supported Islamic populism politics in presidential election (PILPRES) in 2019, they are issues of azan (a prayer's call) restrictions in Masjids, the deletion of religion curriculum, criminalizations of Islamic scholars (ulama'), persecutions of numerous religious activities, and others. ${ }^{39}$

Analyzing it more deeply, all those narrations contain enormous spirits and and various messages portraying discrimination and

${ }^{36}$ Hadiz and Robison, 'Competing Populisms in Post-Authoritarian Indonesia'.

${ }^{37}$ Muzayyin Ahyar and Alfitri Alfitri, 'Aksi Bela Islam: Islamic Clicktivism and the New Authority of Religious Propaganda in the Millennial Age in Indonesia', Indonesian Journal of Islam and Muslim Societies 9, no. 1 (24 May 2019): 1-29.

${ }^{38}$ Ahmad Najib Burhani, 'Lessons from Madura: NU, Conservatism and the 2019 Presidential Election', no. 2019 (2019): 9.

39 'Pilpres 2019 Dihantam Intoleransi?', PinterPolitik.Com (blog), 18 October 2018, https://www.pinterpolitik.com/pilpres-2019-dihantam-intoleransi/. 
structural oppression. These typical narrations indirectly put them in a position of being marginalized groups. Conversely, the label of authoritarianism was pinned to the ruling groups by the descriptions of disaccommodating people's interests. By this, Islamic populism groups would affirm themselves that the politics movement they were taking was people power with the spirit of totality against establishment (anti-establishment), authoritarianism and nativism. Anti- establishment means highlighting values of wisdom to oppose politics power in regard the unfulfilled collective demands. To this group, resisting the authoritarianism implies to construct mass movement for generating one pivot of politics power which according to them reflects people's wills. Meanwhile, nativism in the context of Islamic populism requires political acts and thoughts to conceive that every nation has identity framework and cultural identity as an innate factor in an individual present from birth. ${ }^{40}$ According to the perspective of Islamic populism, a country represents collectively mutual vision determined to achieve the country's ideal aspirations, that is mutual welfare. Therefore, the country is obliged to prioritize their group and restricted to align with outer groups, in this case is the migrant groups.

If Islamic populism problem mentioned above is connected with the phenomena of post-truth, thereby there are numbers of similarities occurred. As minimal similarities as they were found in two things; first, the course of social politics movement is likely to right wing. From the occurance on the last range of time, politics phenomena of post-truth predominantly went through political channels on the right wing basis as it happened in The United States of America, Jair Bolsonaro in Brazil, Dutarte in Philippines, Milos Zeman in Czechoslovakia (2018), Victor Urban in Hungary (2010). These patterns encompass mutuality with global Islamic populism arose in numerous countries in the world such as Islamic groups, Ikhwanul Muslimin, in Egypt, AKP in Turkey played by Endorgan. As with Indonesia, Islamic populism is likely preserved by right wing Islamic groups, either in the form of social organizations as in Hisbut Tahrir Indonesia (HTI) and Islamic Defense Front (Front Pembela Islam FPI), or in the form of political parties as in Partai Keadilan Sejahtera

${ }^{40}$ Lihat Cas Mudde, Populist Radical Right Parties in Europe (New York: Cambridge University Press, 2007). 
(PKS). ${ }^{41}$ Second, the use of religion and identity issues. Populism is identical with popular themes related closely to the lives of grassroot society, particularly those who put self-images as politically and economically marginalized groups. ${ }^{42}$ This pattern has similarities with post-truth which in several occasions tend to use sensitive issues rooted from religion and identity sentiments. In racial politics of post-truth, Trump put much effort to take public attention by throwing racism issue in the form of anti- muslim imigrant politics, accusing muslims as a group of people who should be responsible for series of terror on American citizens. In Indoensia, racism narration of post-truth like Trump's found its resonance with Islamic populism politics, that is when politizations of religion and identity took parts in democracy contest ancy as in Jakarta's governor election (PILGUB) in 2016 and presidential election (PILPRES) in 2018. ${ }^{43}$

\section{PROBLEMS OF ISLAMIC POPULISM AND THE THREATS TOWARD FUTURE DEMOCRACY IN INDONESIA}

From the above discussion, a big question raises up and it is quite intriguing to answer, that is what are the roles and impacts of Islamic populism politics of post-truth toward future democracy in Indonesia? Is Islamic populism politics of post-truth a part of maturing democracy, or instead, is it a threat to the sustainability and the existence of democracy in Indonesia? These two questions are crucial to answer, considering Islamic populism themes and posttruth have so far been attaching Indonesian democracy timelines, both in theoretical and practical politics landscapes as it occurred in Jakarta's governor election (PILGUB) in 2016 and presidential election (PILPRES) in 2019.

In democracy, the freedoms of opinion and alignment are subtantial; it is the representation of expression freedom as intended

${ }^{41}$ Kunawi Basyir, 'Ideologi Gerakan Politik Islam Di Indonesia', Al-Tahrir: Jurnal Pemikiran Islam 16, no. 2 (22 December 2016): 339, https://doi.org/10.21154/ al-tahrir.v16i2.423.

${ }^{42}$ Hadiz, 'A New Islamic Populism and the Contradictions of Development'.

${ }^{43}$ Endang Sari, 'Kebangkitan Politik Identitas Islam Pada Arena Pemilihan Gubernur Jakarta', KRITIS: Jurnal Ilmu Sosial dan Ilmu Politik Universitas Hasanuddin 2, no. 1 (2016): 12. 
in the regulation and legislation. ${ }^{44}$ Still in democracy, information media exists as the funnel of freedom, in which every citizens find freedom in expressing aspiration. Various critics and ideas are admitted as a controling function of optimalization channels towards the ruling authority. Without critics and controls, power legitimation will work authoritatively, and it is highly likely to be misused by particular groups or parties. ${ }^{45}$ As a consequence, in democracy life every effort aiming at blocking freedom of expression in such a way of critics and building alignment conveys the definition of busting the subtantial meaning of democracy.

Indeed, in the ongoing freedom euphoria, it is necessary to be aware of the fact that democratization process in Indonesia is finding its crucial challenges and threats. The vast advancement of technology and information media with all sorts and varities directly brings Indonesian democracy into multiple paradoxical realities. ${ }^{46}$ In this level, technology and information media which earlier played a role as a medium of democracy support, in certain limitations are able to present negative impacts on the existence of democracy itself. The negative impacts refer to the widened and broadened spread of hoax, mass mobilization through political propaganda in social media, radicalization through the widespread of fundamentalist religion content, the increase of hate speech, disinformation, and the worst of all is the deligitamacy of truth concept as it occurred in the voting recapitulation of presidential election (PILPRES) in 2019, when there happened massive movements on social media, both online and offline media, that put efforts to delitigimate the Commission of General Election (Komisi Pemilihan Umum - KPU). ${ }^{47}$ In this situation, the involvement of information media with its advantage

${ }^{44}$ Matthew J. Burke and Jennie C. Stephens, 'Energy Democracy: Goals and Policy Instruments for Sociotechnical Transitions', Energy Research \& Social Science 33 (November 2017): 35-48.iEnergy Research \& Social Science 33 (November 2017

${ }^{45}$ Matthew J. Burke and Jennie C. Stephens, 'Political Power and Renewable Energy Futures: A Critical Review', Energy Research \& Social Science 35 (January 2018): 78-93.

${ }^{46}$ Yudi Latif, Paradoks Demokrasi, Harian Republika, Rabu 17 April 2013. https://www.republika.co.id/berita/kolom/resonansi/13/04/17/mlehcu-paradoksdemokrasi

${ }^{47}$ Wegik Prasetyo, 'Isu Negatif dalam Pemilu 2019: Dampaknya terhadap Legitimasi dan Segregasi Sosial', Jurnal KPU, 2019, 1-18. 
and advancement, in some points has turned out to be a 'boomerang' which threatens democracy life in Indonesia.

Drawing a line of those analyses above onto this study scope, a mutual statement of the problem shows in the phenomena of post-truth politics. Post-truth which has so far been identical with political propaganda and lies widely spread to the media, both online and offline, in practice has not only caused tidings in Indonesian democracy, but also, worse than that, has threatened the existence of Indonesian nationhood which has been known as plural for long. In post-truth politics, when lies and intimidations are taken as political pathways, accordingly at the same time the rooms for discourses encounter crisis of wisdom and ethics. Politics dialectics are not built on the basis of productive thoughts, but more on destructive dialectics. ${ }^{48}$ Along with the use of Islamic populism politics, the use of identity and religion issues in democracy life will be in the same state of what happened in the last several years. Instead of maturing democracy, the reality is repulsing democracy alone. ${ }^{49}$

Theoretically, the problem of Islamic populism politics in the middle of post-truth politics uprise in contemporary Indonesian democracy can be viewed from two ways; First, the massive occurrence of sentiments on particular identity and religion which leads to intolerance attitude and behavior. In this context, racial politics of post-truh in Indonesia which in practice frequently rides on Islamic populism possesses great consequences to the revival of religion sentiment and the growing of exclusivism acts. These two acts will in turn destruct nationhood, trigger clashes and conflicts in the name of identity and faith groups. In Indonesian democracy, threats toward diversity become a crucial matter, considering Indonesia is a pluralistic country consisting enormous varieties of diverse plurality in culture, ethnicity, race, and religion. Exclusivism potentially makes an individual or a group to be exclusive to live aside with outer groups (belief). In Indonesian case, the threat to post-truth politics problem on the basis of Islamic populism is hard to belittle and underestimate,

${ }^{48}$ Dinna Wisnu, Friedrich-Ebert-Stiftung, and Indonesia Office, Populism, identity politics and the erosion of democracies in the 21st century: a reflection from Bali Civil Society and Media Forum 2018, 2019, http://library.fes.de/pdf-files/bueros/ indonesien/15936.pdf.

${ }^{49}$ AG. Eka Wenats Wuryanta, 'Post-Truth, Cyber Identity dan Defisit Demokrasi', preprint (Open Science Framework, 7 August 2018). 
since there are findings from several survey institutions that the trend on the number of religious intolerance in Indonesia in the last few years has increased. ${ }^{50}$ The trend on such change was triggered by the revival of political use of identity and religion, particularly after the huge mass mobilization of Islamic Defense Action (Aksi Bela Islam) 212 and 411 during a democracy party of Jakarta's governor election (PILGUB) in 2017.

Second, besides religious intolerance aspect, the problem of Islamic populism politics use towards democracy life in Indonesia, it can also be seen on the high rate of intolerance in political sector. In Indonesia, since the end of reformation 1998 which was marked by the fall of Soeharto authoritarian regime, political constellation under the leadership level ran smoothly, dynamically, andovertly. Political power was no longer monopolized by merely a group or class, yet it was generally open for all public elements without exception. Constitutionally, the open process of power succession in Indonesia was reflected evidently from the implementation of totality democracy system, in which the system provided the public full discretion to build and create political alignment. This discretion then generated a new paradigm in national party system, which is now known as multi-parties system. Accordingly, there has no longer been practices of political party limitation unlike it used to be found in the era of new order.

However, after a couple of decades, totality democracy as Indonesian politics system and governance found burdened impedance and obstruction in its politics freedom. It appeared as a result of the inclined acts and behavior of political intolerance. In several occasions, according to studies conducted by numerous survey institutions, political intolerance in Indonesia was observed from the resistance of social groups toward the existence political leader outside their circle groups. The strengthened acts and behavior of Indonesian political intolerance seemed to find its relevance by the lowered rate of democracy in Indonesia. This was proven by the data from The Economist Intelligence Unit, which reported that Indonesian democracy rank had declined, as it was ranked in 48 then declined to

${ }^{50}$ Ezra Sihite, 'Survei LSI: Tren Intoleransi Politik Meningkat Dua Tahun Belakangan', vivanews, 3 November 2019, https:/www.vivanews.com/berita/ politik/16855-survei-lsi-tren-intoleransi-politik-meningkat-dua-tahun-belakangan. 
68. ${ }^{51}$ According to a research of the prominent survey institution, it was found that the weakening of Indonesian democracy undergoing at recent time tended to be impacted from the issues of civil freedom and political culture, which from time to time perceiving narrowing as a result of overused issues of culture, ethnicity, race, and religion.

Resonating from the forementioned analyses, the use of Islamic populism politics definitely contains great negative effects on the life of Indonesian democracy. Problems of the use of Islamic populism politics issues do not only bring adverse impacts on the moves of political wheels and governance, but also cause turmoil and great shake on the reality of nationhood.

\section{CONCLUSION}

Phenomena of post-truth global politics which hit many countries in the world, in several recent years have hit Indonesian democracy. In Indonesia, the occurrence of post-truth politics phenomena was characterized by the presence of populistic issues, mainly root from religion and identity primordialism. In Indonesian democracy, the growing of Islamic populism politics can be found in every politics stage, enduring both in regional level and national level. In regional level, the real portrait of Islamic populism politics can be viewed in a phenomenon of Ahok during Jakarta's governor election (PILGUB) in 2017, which then was followed by a huge religious mobilization, Islamic Defense Action (Aksi Bela Islam) 212 and 411. Meanwhile in national level, Islamic populism politics can be found in political narration of presidential election (PILPRES) in 2019, when primordialism issues were numerously used.

Political narration problems of post-truth and Islamic populism politics toward the construction of Indonesian democracy system are generally viewed in two aspects; First, the inclined acts and intolerance behavior in religion characterized by the loosen inclusivism, in which at the same time, the rise of exclusivism and majoritarianism allowing it to end up in sentimental acts, either in the name of religion such as the burning of worship places, persecutions of religious events,

${ }^{51}$ Dian Erika Nugraheny, 'Indeks Demokrasi Indonesia Turun Dalam Tiga Tahun Terakhir', KOMPAS.COM, 24 January 2020, https://nasional.kompas.com/ $\mathrm{read} / 2020 / 01 / 24 / 20340031 /$ indeks-demokrasi-indonesia-t urun-dalam-tiga-t ahunterakhir-ini-respons?page $=$ all. 
and alike; Second, the inclined acts and intolerance behavior in political sector. Practically the use of Islamic populism politics in Indonesian contemporary democracy life does not only heaten up and roar political dynamic in Indonesia, but also entirely threaten the construction of Indonesian democracy system and its order.

By underlying such findings, the study consists of theoretical implication that the occurrence of Islamic populism politics was a contemporary social religious reality regarding strong relations with phenomena of post-truth in global politics. This simultaneously supported the study by Vedi R. Hadiz suggesting that Islamic populisms tend to convey 'political resistance' movements of right wing Islamic groups in Indonesia, which in the last several years seemed to be marginalized by the government policy that does not take their interests into account.

\section{REFERENCE}

'A Government of Lies" by Tesich, Steve - The Nation, Vol. 254, Issue 1, January 6, $1992^{\circ}$ Online Research Library: Questia Reader'. Accessed 21 June 2020. https://www.questia.com/ $\mathrm{read} / 1 \mathrm{G} 1-11665982 /$ a-government-of-lies.

Abdi, Supriyanto. 'Muslim Politics and Democracy In Indonesia'. Jurnal Millah 6, no. 1 (Agustus 2007): 17.

Ahyar, Muzayyin, and Alfitri Alfitri. 'Aksi Bela Islam: Islamic Clicktivism and the New Authority of Religious Propaganda in the Millennial Age in Indonesia'. Indonesian Journal of Islam and Muslim Societies 9, no. 1 (24 May 2019): 1. https://doi. org/10.18326/ijims.v9i1.1-29.

A'la, Abd. Jahiliyah Kontemporer Dan Hegemoni Nalar Kekerasan. Yogyakarta: LKiS, 2014.

Alwi, Hasan. Kamus Besar Bahasa Indonesia. Jakarta: Balai Pustaka, 2007.

Amilin. 'Pengaruh Hoaks Politik Dalam Era Post-Truth Terhadap Ketahanan Nasional Dan Dampaknya Pada Kelangsungan Pembangunan Nasional'. Jurnal Kajian Lemhannas RI 36, 
no. (September 2019). http://www.lemhannas.go.id/images/ Publikasi_Humas/Jurnal/Jurnal_Edisi_39_September_2019. pdf.

Arifin, Syamsul, Hasnan Bachtiar, Ahmad Nur Fuad, Tongat Tongat, and Wahyudi Wahyudi. 'Minority Muslims and Freedom of Religion: Learning from Australian Muslims' Experiences'. Indonesian Journal of Islam and Muslim Societies 9, no. 2 (25 December 2019): 295-326. https://doi.org/10.18326/ijims. v9i2.295-326.

Bagherzadeh Samani, Bahareh, Hossein Pirnajmuddin, andBehnoush Akhavan. 'Paul Virilio's Dromology and the Postmodern City in Don DeLillo's Cosmopolis'. Edited by Maria DiBattista. Cogent Arts \& Humanities 5, no. 1 (1 January 2018): 1424600. https://doi.org/10.1080/23311983.2018.1424600.

Barton, Greg. "The Prospects for Islam". In Indonesia Today: Challenges of History. Singapore: Institute of Southeast Asian Studies, 2001.

Bartram, Rob. 'Visuality, Dromology and Time Compression: Paul Virilio's New Ocularcentrism'. Time \& Society 13, no. 2-3 (27 August 2004): 285-300. https://doi. org/10.1177/0961463X04044577.

Basyir, Kunawi. 'Ideologi Gerakan Politik Islam Di Indonesia'. AlTahrir: Jurnal Pemikiran Islam 16, no. 2 (22 December 2016): 339. https://doi.org/10.21154/al-tahrir.v16i2.423.

Burhani, Ahmad Najib. 'Lessons from Madura: NU, Conservatism and the 2019 Presidential Election', no. 2019 (2019): 9.

Burhani, Ahmad Najib, and Deasy Simandjuntak. 'The Ma'ruf Amin Vice-Presidential Candidacy: Enticing or Splitting Conservative Votes?' ISEAS - Yusof Ishak Institute 51, no. 2018 (4 September 2018): 8.

Burke, Matthew J., and Jennie C. Stephens. 'Energy Democracy: Goals and Policy Instruments for Sociotechnical Transitions'. Energy Research \& Social Science 33 (November 2017): 3548. https://doi.org/10.1016/j.erss.2017.09.024. 
'Political Power and Renewable Energy Futures: A Critical Review'. Energy Research \& Social Science 35 (January 2018): 78-93. https://doi.org/10.1016/j.erss.2017.10.018.

Curato, Nicole. 'Politics of Anxiety, Politics of Hope: Penal Populism and Duterte's Rise to Power'. Journal of Current Southeast Asian Affairs 35, no. 3 (December 2016): 91-109. https://doi.org/10.1177/186810341603500305.

Fischer, Frank. 'Knowledge Politics and Post-Truth in Climate Denial: On the Social Construction of Alternative Facts'. Critical Policy Studies 13, no. 2 (3 April 2019): 133-52. https:// doi.org/10.1080/19460171.2019.1602067.

Garadian, Endi Aulia. 'Membaca Populisme Islam Model Baru'. Studia Islamika 24, no. 2 (2017): 379-93. https://doi. org/10.15408/sdi.v24i2.5708.

Hadiz, Vedi. 'Imagine All the People? Mobilising Islamic Populism for Right-Wing Politics in Indonesia'. Journal of Contemporary Asia 48 (6 February 2018): 1-18. https://doi.org/10.1080/00472 336.2018 .1433225 .

Hadiz, Vedi R. 'A New Islamic Populism and the Contradictions of Development'. Journal of Contemporary Asia 44, no. 1 (2 January 2014): 125-43. https://doi.org/10.1080/00472336.201 3.832790 .

Title-Page. In Islamic Populism in Indonesia and the Middle East. Cambridge: Cambridge University Press, 2016.

Hadiz, Vedi R, and Richard Robison. 'Competing Populisms in Post-Authoritarian Indonesia'. International Political Science Review 38, no. 4 (1 September 2017): 488-502. https://doi. org/10.1177/0192512117697475.

Hannan, Abd. 'Firehouse of Falsehood; Politik Pascakebeneran Dan Ancamannya Terhadap Bangunan Demokrasi Indonesia'. In Digital Islam, Education and Youth; Changing Landscape of Indonesian Islam, Vol. 19. Belgium: Euoropean Alliance fo Innovation (EAI), 2019. 
'Kembalinya Politik Identitas'. DetikNews, 3 January 2018. https://news.detik.com/kolom/d-3796760/kembalinyapolitik-identitas.

Haryatmoko. Dominasi Penuh Muslihat. Jakarta: Gramedia, 2010.

Hilmy, Masdar. Islamisme and Democrazy in Indonesia. Sinagapore: Institute of Southest Asian Studies, 2010.

- Teologi Perlawanan,: Islamisme Dan Diskursus Demokrasi Di Indonesia Pasca Orde Baru. Yogyakarta: Kanisius, 2009.

Hofmann, Steven Ryan. 'Islam and Democracy: Micro-Level Indications of Compatibility'. Comparative Political Studies 37, no. 6 (1 August 2004): 652-76. https://doi. org/10.1177/0010414004265881.

Jati, Wasisto Raharjo. 'Radicalism in the Perspective of IslamicPopulism: Trajectory of Political Islam in Indonesia'. JIS; Journal of Indonesian Islam 7, no. 2 (1 December 2013): 268. https://doi.org/10.15642/JIIS.2013.7.2.268-287.

Kadir, Hatib Abdul. 'Islamic Populism in Indonesia and the Middle East, Written by Vedi R. Hadiz'. Bijdragen Tot de Taal-, LandEn Volkenkunde / Journal of the Humanities and Social Sciences of Southeast Asia 173, no. 4 (1 January 2017): 594-97. https:// doi.org/10.1163/22134379-17304011.

Kusumo, Rangga, and Hurriyah Hurriyah. 'Populisme Islam di Indonesia: Studi Kasus Aksi Bela Islam oleh GNPF-MUI Tahun 2016-2017'. Jurnal Politik 4, no. 1 (15 February 2019): 87. https://doi.org/10.7454/jp.v4i1.172.

Lakoff, Robin. 'The Hollow Man: Donald Trump, Populism, and Post-Truth Politics'. Journal of Language and Politics 16 (12 June 2017). https://doi.org/10.1075/jlp.17022.lak.

Mudde, Cas. Populist Radical Right Parties in Europe. New York: Cambridge University Press, 2007.

Nugraheny, Dian Erika. 'Indeks Demokrasi Indonesia Turun Dalam Tiga Tahun Terakhir'. KOMPAS.COM, 24 January 2020. https://nasional.kompas.com/read/2020/01/24/20340031/ 
indeks-demokrasi-indonesia-turun-dalam-tiga-tahun-terakhirini-respons?page $=$ all.

Nur Rohmah, Siti. 'Critical Discourse Analysis of Donald J Trump's Speeches’. UIN Sunan Ampel Surabaya, 2018.

Paul, Christopher, and Miriam Matthews. The Russian 'Firehose of Falsehood' Propaganda Model: Why It Might Work and Options to Counter It. RAND Corporation, 2016. https://doi. org/10.7249/PE198.

PinterPolitik.com. 'Pilpres 2019 Dihantam Intoleransi?', 18 October 2018. https://www.pinterpolitik.com/pilpres-2019dihantam-intoleransi/.

Prasetya, Rendy. 'Criticizing Russian Propaganda Firehose of the Falsehood from the Framework of Social Network Analysis', 21 November 2019.

Prasetyo, Wegik. 'Isu Negatif dalam Pemilu 2019: Dampaknya terhadap Legitimasi dan Segregasi Sosial'. Jurnal KPU, 2019, $1-18$.

Provencher, Nicholas. 'Is Islam Compatible with Democracy: A Critical Reexamination of Existing Theory to Establish Renewed Potential'. Prosiding, University of Arkansas at Monticello, Georgia, 2011.

Qohar, Abd. 'Politik dan Islam di Indonesia'. Jurnal TAPIs 14, no. 2 (2017): 8.

Rose, Jonathan. 'Brexit, Trump, and Post-Truth Politics'. Public Integrity 19, no. 6 (14 November 2017): 555-58. https://doi.org /10.1080/10999922.2017.1285540.

Rosenberg, Matthew, Nicholas Confessore, and Carole Cadwalladr. 'How Trump Consultants Exploited the Facebook Data of Millions'. The New York Times. 17 March 2018, sec. U.S. https://www.nytimes.com/2018/03/17/us/politics/cambridgeanalytica-trump-campaign.html.

Sari, Endang. 'Kebangkitan Politik Identitas Islam Pada Arena Pemilihan Gubernur Jakarta'. KRITIS: Jurnal Ilmu Sosial dan Ilmu Politik Universitas Hasanuddin 2, no. 1 (2016): 12. 
Sihite, Ezra. 'Survei LSI: Tren Intoleransi Politik Meningkat Dua Tahun Belakangan'. vivanews, 3 November 2019. https://www. vivanews.com/berita/politik/16855-survei-lsi-tren-intoleransipolitik-meningkat-dua-tahun-belakangan.

Speed, Ewen, and Russell Mannion. 'The Rise of Post-Truth Populism in Pluralist Liberal Democracies: Challenges for Health Policy'. International Journal of Health Policy and Management 6, no. 5 (12 February 2017): 249-51. https://doi. org/10.15171/ijhpm.2017.19.

Vicsek, Lilla. 'Halim Rane, Jacqui Ewart, John Martinkus: Media Framing of the Muslim World. Conflicts, Crises and Contexts.' KOME 4, no. 1 (2016). https://doi.org/10.17646/ KOME.2016.17.

Washington Times. 'Stephen Colbert's "truthiness" Word Describes Campaign Rhetoric'. Washington Times, 18 August 2016. https://www.washingtontimes.com/news/2016/aug/18/ stephen-colberts-truthiness-word-describes-campaig/.

Wight, Colin. 'Post-Truth, Postmodernism and Alternative Facts'. New Perspectives 26, no. 3 (1 October 2018): 17-29. https:// doi.org/10.1177/2336825X1802600302.

Wisnu, Dinna, Friedrich-Ebert-Stiftung, and Indonesia Office. Populism, identity politics and the erosion of democracies in the 21st century: a reflection from Bali Civil Society and Media Forum 2018, 2019. http://library.fes.de/pdf-files/bueros/ indonesien/15936.pdf.

Wuryanta, AG. Eka Wenats. 'Post-Truth, Cyber Identity dan Defisit Demokrasi'. Preprint. Open Science Framework, 7 August 2018. https://doi.org/10.31219/osf.io/up96m. 